\title{
機械の確定的危険源に関する安全規制についての基礎的考察* (労衝安全衛生規則が定める危険源)
}

\author{
加部隆 史 ${ }^{* 1}$, 梅 崎重 夫*2, 杉本 旭*3 \\ Basic Consideration on Safety Regulations Based \\ on Deterministic Hazards of Machinery \\ (Hazards, Defined by Occupational Health and Safety Regulation)
}

Takashi $\mathrm{KABE}^{* 4}$, Shigeo UMEZAKI and Noboru SUGIMOTO

${ }^{* 4}$ NPO The Safety Engineering Laboratory,

3-39-8 Shoan, Suginami-ku, Tokyo, 1670054 Japan

\begin{abstract}
Hazards of machinery are the origin of dangerous situation consisting out of hazard and worker. Therefore it is to be regulated, that hazards will be eliminated or the risk caused by dangerous situation will be reduced according to principles of safety for machinery according to well-tried best engineering practice and state of the art. Similar fatal accidents happen continuously especially by roll-in or crashing due to driving energy source of machinery. Analysis of certain fatal accidents show, that principle of safeguarding add principle of stopping were not properly appued and this means fatal accidents were foreseeable and avoidable, if the above mentioned two principles of safety were effective Japanese laws on occupational health and safety contain already deterministic hazards nd indicate the way, how to treat them, even so this will not always be practiced in work places. Certain reasons thereof were investigated and practical advices were given to improve the situation in workplaces.
\end{abstract}

Key Words: Risk-Based Design, Safety Engineering, Safety Regulation, Justice

\section{1. 粕苔}

機械設備に関する労働災害は，危険源と人が同一時 刻に, 同一場所に物理的に共存寸る事(図 1-1)により発 生寸る危険事象(図 1-2)のなかで, 危険源の処理が適切 になされていないか，人が規則をまもらないかを主要 因として発生する. 適切な安全の原則を適用し, 設計 者は危険源に起因するリスクの低减措置をその時代の 最新の科学及び技術の知見に基づき合理的な代替設計 がないところまで追求し，その限界を残留リスクの情

* 原稿受付 2008 年 6 月 23 日.

*1 正負, NPO 安全工学研究所 (严 167-0054 東京都杉並区松庵 $3-39-8)$.

*2 正員, (独)労働安全衛生総合研究所(严204-0024 清瀬市梅 園 1-4-6).

*3 正員, フェロ一, 長岡技術科学大学大学院技術経営研究科シ

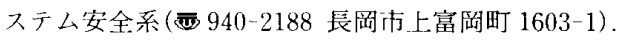

E·mail : kabe@safetylabo.com
報として適切に使用者一伝達し，使用者はそれを守り かつ適切な管理を実践する事により，これらの多くの 労働災害は事前の予防措置により回避可能である.

これは, 安全の基本原則としての隔離の原則(図 1-3) 或いは停止の原則（図 1-4）を厳守する事により達成 される. 停止の原則の場合，主たる危険源で有る機械 の動力源の状態を人が介入する際に，如何にエネルギ 一・ゼロの状態を保つかに有る. 主電源の管理,イン ターロック装置の制御回路が安全回路になっている事 と故障検出の方法が重要となる. 又, 緊急停止用とし て非常停止スイッチが使用される。この場合，作業の 效率性の観点から安全装置を無効化する，或いは隔離 の原則において，動力源を遮断せずに直接危険源に接 近する事で, 特に機械の保守点検作業や情掃作業の際 に往々にして行なわれ，安全の原則が守られずに事故 
に槃がる.

本稿では，災害につながる危険事象の発生源のひと つである確定的な危険源に着目し，それが安全規制と してどのように扱われているかを，国内と国外の実態 を踏まえ，どのような安全規制が望ましいかを検証す る. その際に留意すべき点は，安全をどこまでやるか という問いに対し，危険源の工学的取扱は，科学技術 に由来するもので有るが為に価值を含まないが，安全 規制となると法学・経済学・政治学・倫理学等が背景 として考慮される為に価值が入る．安全は人権から出 発している為に，単に確定的危険源の対処に対し設計 者の限界を示し，残留リスクの管理を使用者に託すと いう工学的視点のみでは完結する事は出来ずに，正義 及び費用便益性などが反映されている実社会との係わ りから後者への配慮をもって初めて安全の達成方法の 客観化がなされる，通常有する安全性の概念は，各国 の慣行，経済性等を考慮したうえで定められる事にな っている.

本稿では第 2 章で国内の労働災害の典型例を分析し, そこでは必ずしも確定的危険源を定めた国内規則が守 られていない事例が多数かつ繰返し存在する実態を把

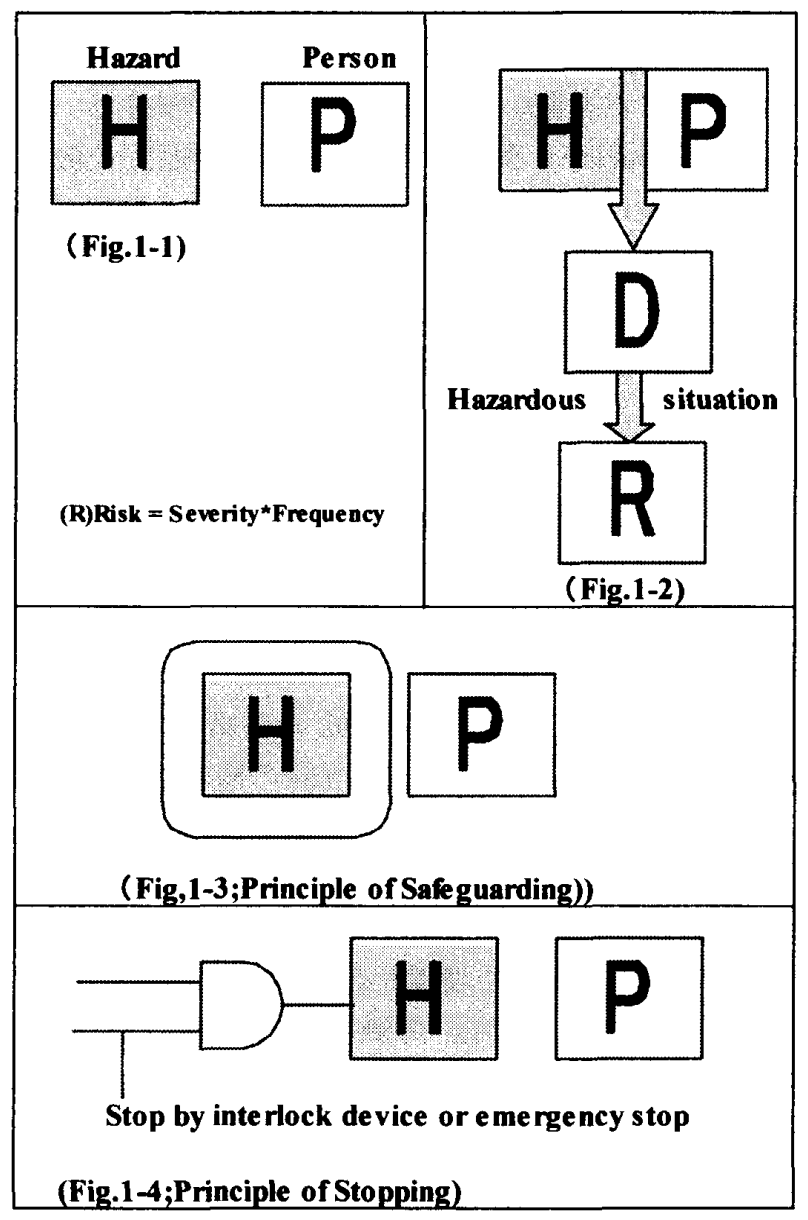

Fig. 1 Hazard + Person = Hazardous Situation
握し，第3 章で国際規格と日本の安全規制に共通する 確定的危険源に基づく安全の原則である「隔離の原則」 と「停止の原則」の法律一の反映状況を比較検討し, 䂆方と補償の観点加ら日本の場合の法令遵守に関寸る 社会的背景を考察し，第 4 章では各々の利害関係者の 置かれた立場で安全との関連性を考察する．第 5 章で は安衛法第 28 条関連のリスク・ベースに基づく概念の 導入とその意義並びにそれに伴う更なる課題を検証し， 最後に明治時代の工場法から危険源に対する安全規制 が国内で実践されているが，国際情勢と比較した際の 肯定的側面と否定的側面を整理し，今後の国内での安 全規制の運用についての提案を行なうものである.

\section{2. 労的災害の典型例}

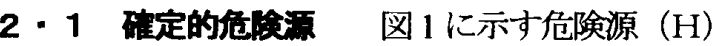
は，物理的に存在しかつ一定であり，信頼性のバスタ ブ曲線の様に時間の経過と共に一定期間减少するもの ではない(1). その為に，機械のライフサイクルに亘り 対処されていない危険源は，常にリスクに熬がる。 す なわち，病原菌と同様にその危険源を除去するか或い は隔離するかのいずれかの方策が感染を防止するには 必要となってくる. リスクは図 1-2 に示寸危険事象

（D）で，すなわち人が介入する事により，初めて発 生する概念である為, リスク発生以前に確定的危険源 から演繹される事故に対する設計的な対応がなされて いれば，有効な予防措置へとつながる．図 1-1 は，危 害の要素である危険源と人をあらわし，図1-2 は，危 険源 $(\mathrm{H})$ と人 (P) が同一空間でかつ同時刻に遭遇し た際に，危険状態 (D) が育成され，そこでリスク（R) が発生することを示している. リスクからの危害を防 止する為に, 図 1-3 は危険源と人を分離する隔離の原 則を示し，図 1-4 は危険源へのエネルギ一投入を遮断 する停止の原則を示している.

ソフトウェアが関連する場合は，信頼性に基づく確 率的な危険源が存在するが，本稿ではこれを考察の対 象外とする.

$2 \cdot 2$ 労的災豈事例 ここ数年間の国内での労 働災害統計を検証すると，死亡事故の場合，凡そ2 割 が製造業，そのうち凡そ 3 割がはさまれ・巻きこまれ に起因寸る事がわかる。これらは大方機械の動力源へ の安全方策が適切ではなかった，或いは，作業者が安 全の原則を守らなかったことに起因する．あらゆる機 械の駆動源が危険源であることは明白であり(事故の 予見可能性), それに対し定常作業については覆いや囲 
いという隔離の原則を適用し，非定常作業については 動力遮断による停止の原則を適用することにより，本 来およそ 8 割の事故は確定的危険源を演繹的な予防措 置により設計段階において回避可能であり，再発防止 も可能である(2)(3).

以下に，製造業での労働災害の凡そ 3 割近くを占め る「はさまれ・捲き込まれ」に関する混合機及びベル トコンベア等, 最近の災害事例を検証する.

中央労働災害防止協会，死亡災害データベース 混合機, 平成 11 年,

死亡 13 件，うち9件がはさまれ，捲き込まれ 主要因： 清掃作業, 保守点検作業, 材料投入作業, 異物混入取除き作業＝大半が非定常時

中央労働災害防止協会，死亡災害データベース コンベア，平成 11 年

死亡 20 件，うち 14 件がはさまれ，捲き込まれ 主要因：清掃作業, 保守点検, 取除き作業, 異物 混入取除き作業 $=$ 大半が非定常時

鉱業労働災害防止協会,

リスクアセスメントを活用した「はさまれ・捲き込 まれ」㷋害防止対策事例集，平成 19 年 3 月

平成 14 年から 16 年の間に 570 名が休業 4 日以上の 労働災害の被災者となった. 内訳は，壁落・転落 140 名, はさまれ・捲き込まれ 135 名, 以下飛来・落下 67 名，転倒 47 名など．本事例集ではうちベルトコ ンベアを中心として 38 事例を紹介している.ここで も，同様に大部分の災害は，上述の通り非定常時に 発生し，機械の防護が施され，停止の原則を守って いれば回避可能であったと言える。

\section{3. 国際規格と日本の安全規制}

3・1 国的想格 安全規制を国が実施する方法 として，日本のように国が詳細に亘る安全基淮を策定 するか，欧州のように機械の危険源への対応を製造者 に責任を課し，法的枠組みで安全の達成目標のみを定 め，達成方法は民間の規格などを活用する方法，或い はアメリカのように基本的な安全規制を行なうと共に, PL 法などによる制裁への予防措置として危険源への 取組みを設計段階で奏施する等，いくつかの方式が有 る.

国際的に安全規制を取り巻く背景として，近年では 以下の 3 点が重要な要素となっている;

1) OECD 規树改革 経済協力開発機構(OECD)加盟 国で社会保障の肥大化により大きな政府となり財政問
題が発生した事に対し，様々な規制を撤廃するという 行政改革の波.

2)WTO/TBT 奻定 世界貿易機構(WTO)・貿易の技 術的障害に関する協定(TBT 協定)による経済活動の障 害を国境を越えて是正する動きで, その為に基淮認証 制度の標準化が重要. 要するに，国が法律で策定する 技術基淮は，科学技術の急速な進歩に追従できず，か つ法律の総体数が削堿できないという問題点の克服の 為に，第 2 条 8 項では性能規定化を定めている，その 為，性能規定化により法律では方向性のみ示し，民間 で策定された規格を運用するという仕組みが提示され ている.

3) 人售産業革命以降に多くの被災者が出た事 により，新たな社会権として「労働者の権利」がドイ ツなどでは確立された $(4.4$ 項参照) . 又，1960年代 の環境問題等に起因して，新しい人権として，「知る 権利」が工業先進諸国では確立してきており，ドイツ 連邦日本法の第 5 条 1 項にこれは明記され，世界人権 宣言の第 19 条にも規定されている.労働災害に関して 重要なのは, 後述する国際労働機構(ILO)条約第 119 号 機械防護条約である.

3・2 日本の安全规制 安全はそもそもが生 命・自由及び幸福追求の権利の一環としての人権問題 であり，それを妿か寸危険からの開放を意味する

(ISO/IC Guide 51 参照) が，他の工業先進国と比較し 日本の場合には後述の労働者の権利及び知る権利が基 本的に久落しており，4·3 項で示すとおり，安全は人 権から出発しておらず，経済面の利害が比較的優先さ れ達成されてきた，安全規制の結果としての労働災害 死亡者数は, 日本の場合平成 18 年の厚生労働省の統計 による確定值では全産業で 1472 名, ドイツの場合ドイ ツ職業保険組合 HVBG によると 2006 年で 646 名，イ ギリスの場合安全衛生庁 HSE の統計では 2006 で 241 名であり，統計が示す通り，明らかに日本の場合には 改善の余地を残している.

明治 44 年に工場法が制定され，その第 1 条で, 事業 の性質危険なるものとしてこの法律の適用範囲が定め られ，それを受け昭和 4 年に，工場危害予防及衛生規 則が定められた。この規則では原動機，動力伝動装置 或いは，その調帯等を危険なもの(危険源)として明文 化し，棚囲又は被覆を設置するよう機械防護の基本が うたわれている．その後，労働基準法が昭和 22 年に制 定され，そこから派生して昭和 47 年に現在に至る労働 安全衛生法(以下，安衛法)及び安全衛生規則（以下， 安衛則）等が制定された。危険源の扱いについては, 
当初の法律の方が法律名に危険という表現を用いてお り明確である様に見受けられる.

昭和 48 年には，ILO第 119 号条約（機械防護条約） に日本が批准した．ここでは，(1)危険な機械で防護無 きものは国内法で流通を禁止すべし(2)労働者は安全装 置のない機械を使用す心゙きでないとしている．実際に は，日本では(1)該当するのは特定機械に限定され， 大方の機械は，本来国内法で定めて有る危険源への対 象が明確ではなく，解釈上特定機械以外は，規制対象 外であると解釈されるふしがある，(2)につては，日 本で労働者の権利なるものが存在しない為にこのよう な行動を労働者は実行しかねる。

平成 17 年に安衛法第 28 条の 2 が改正され，これに 伴い事業者へのリスクアセスメントの努力義務が課せ られた. 欧州では，事業者へ対し 1992 年に欧州指令に よりリスクアセスメントの実施義務が課せられたと同 時に機械製造者については設計者責任を定めた上での 流通許可に関する欧州機械指令による自己宣言制度

(CE マーキング) が 1993 年から導入されている.こ こには，ふたつの制度の運用を比較すると，13 年間の 時代の隔離と努力義務力罰則付きの強制法規かの大き な差異が存在する.

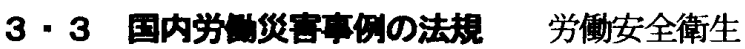
法(以下, 安衛法) 第 20 条の 1 を受けた現在の安全衛 生規則（以下，安衛則）には，表 1 が示すとおり，隔 離の原則, 停止の原則, 更には安全装置の無効化禁止, エネルギー・ゼロ・ステート, ホステージ・コントロ 一ルとロックアウト・タグアウト, 命鍵等の欧米の安 全に関する基本原則が既に取入られている. 又, 杉本・ 莲原は安全確認型の安全の原理を国際規格体系の全貌
が明らかにされる前に発表している(図 1-4 参照) ${ }^{(4)}$. I LO 機械防護条約の実際の運用上の不備は存在するも のの，確定的な危険源，ひいては基本的な安全原則を 配慮している事は，国際的に見ても評価されるところ である.ただし，現在の機械類の安全に関する国際規 格体系は，それを階層化・体系化し具体的なリスク低 减方法を明示した事で更に進化している.

$2 \cdot 2$ 項の例いずれもの大部分の事例については，安 衛法第20 条第 1 号及びそれを受けた安衛則の特に下記 条項が該当する；

第 101 条（原動機，回転軸等による危険の防止）

第 107 条（そうじ等の場合の運車停止等）

第 151 条の 78 (非常停止装置)

第 143 条（内容物を取り出す場合の運転停止）

等，法律で規定されている「隔離の原則」及び・或い は「停止の原則」が遵守されていなかった事に起因す る. 寸なわち，事故は予見可能で，危険源への対応を 規定した規則への法令順守により結果回避可能であっ たという事になる．その他主な安全原則に該当する条 文を表 1 に示す.

すなわち，機械安全に関する国際規格でうたわれて いる安全の諸原則を持ち出すことをなくして，国内法 規で確定的な危険源が列挙され，隔離の原則及び停止 の原則が明示されているという事である. それにもか かわらず, 同じような事故が幾度と無く繰り返され， 尊い命が依然継続的に犠牲となっているのは，上記安 全の原則や規則が，現実として守られていない事を意 味する．事故が起きても，人が介入する非定常時作業 が多い為に，多くの場合は作業者の注意不足とされ， 機械の設計者は安全の原則を守ったか，機械の使用者

Table 1 Safety principle, relevant legislation and international standards

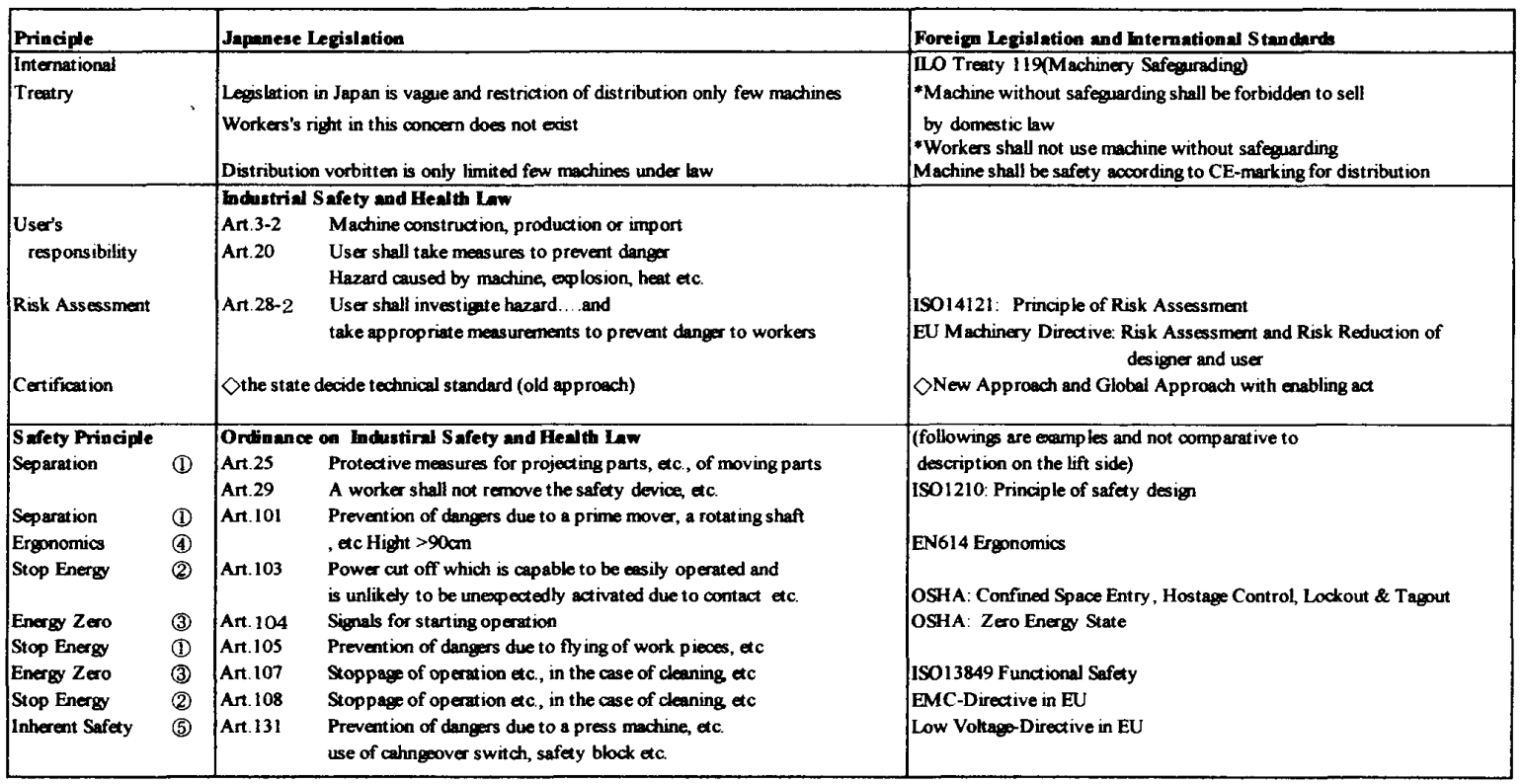


は安全配慮の措置を実施したかは，殆ど問われること が無い.

すなわち，本来ならば安衛法に従い，機械製造者は 機械防護と停止の手段を施した機械を市場に流通させ, 機械使用者は職場の安全と健康を配虑する義務を有す るわけであり，もし機械防護が不充分であればそれを 機械製造者に是正させる或いは，自ら追加的保護方策 を講じる事が道理である.これらが不充分な状態で, 作業者が事故を起こすと，その原因が作業者の注意不 足となる事は正義に適っているかを熟慮する必要性が 有る.

3-4 法の正用実㛝 それでは，何故これら明 文化されている安全原則が第2 章で述べたように守ら れないかを考察する必要が有る.

1）間接的責任 危険源の管理が製造者となってお らず，事業者の為，機械自体の危険源に事業者として は的確に対応できかねる事. 機械の危険源を生み出す 製造者には，その対応が安衛法では要求されておらず 間接的な責任しか及ばない。

2）製造者には，製造物責任法が民事的に対象となり

うるが，国内の場合訴訟になる事例数が欧米諸国と比 較すると著しく少ない為に，この法律の運用実態は芳 しくない，又，万が一訴訟となっても大多数が和解で 解決し経済的には製造物責任保険で補償は補填され， 実質的には，事後救済が貫徹し，安全設計による予防 方策につながらない。

3）取締り法規である安衛法の条文が，あたかも性能 規定の様に漠然とした表現で，現実に取締ることがで きない．欧米のように規格が事実上強制法規と同様な 力を持たない限り，実質上規制は不可能であろう。

4）欧米やオセアニア諸国で実践された規制改革の手 法により，民主導の基淮認証制度に移行しようとして も，民自体の自主性が歴史的に育成されてこなかった 為に，実行面で支障が発生している.

同時に，中立的な第三者認証機関が殆ど育成されて こなかった事により，設計者は自らの設計結果の安全 に関する妥当性検証が赛行しづらく，又それを達成す る手法についての相談も行なえないという状況が有る. これに伴い，技術に特化した安全専門家の育成がなさ れてこなかった事もその大きな一因である.

5）日本人の法意識 以下に法律の背景となる日本 人の法意識につき考察する. 敗戦值後の 1946 年 5 月

15 日に文部省から発表された「新教育指針」第 1 分冊 での記述を以下に引用する；

明治維新以来の日本は，西洋文化を急いで取りいれ， それによって近代化した.けれどもそれは主として西
洋文化の物質方面，もしくは外がわの形を学んだので あつて，その根本の精神，またはその中にある実質は まだ十分に取りいれてみないのである. 例一ば汽車や 汽船や電気器具を使ふことは学んでも，それらをつく りだしたところの科学的精神そのものは，まだ十分に 発展させてみない：憲法政治や議会制度の形式を取り いれても，それらの実質すなはち人の権利を尊重する ことや自由な意志による政治といふことは，まだ十分 に実現されてをらない.

…. ひはん的精神に欠け，権威にまう従しやすい 国民にあつては，物事を道理に合せて考へる力，すな はち合理精神がとぼしく，したがつて科学的なはたら きが弱い.ここでは権利意識の薄さと科学を飛ばして 技術・技能一と集中した日本の実態が描写されている. この状況は，半世紀以上経過した現在でも殆ど変化が 見られない.

更に，政治学者・社会学者である丸山占は日本人の 責任感につき戦前戦中の日本は無責任体制．日本人は 集団では強いが個人では弱く責任をとろうとしない． 日本人にはヨーロッパ人のような自我が無いため，責 任をどこかに転蝊してしまう，と表現している.

イギリスの労働安全行政改革のきっかけとなった口 一ベンス報告の骨格である自主管理(enabling act)を国 内で実践しようとしても，これまで(自我に基づく)民 主体の動きが育成されてきていない為に，制度を移行 しただけでは実際に機能するには至らない．

日本人の法意識として法学者の川島 ${ }^{(6)}$ が指摘するよ うに権利の概念が欠けるという特質が有る. 法とは, 語源として英語の justice(正義)或い 、独語の Recht（権 利）があるが，日本の場合には，法とは国からの取締 法，実定法の法解釈という事に主眼が置かれており， 国際条約，国際機関，国際規格等の源である正義或い は権利から出発していない．欧米の市民社会では権利 は闘いにより，尊い多くの命が儀牲となった代偵とし て獾得したものであるが，日本の場合権利は国から与 えられたもので，そこに根本的な意識の差異が存在し ている.

又，技術者の市川は（日，日本は一神教が社会に浸透 しなかった極めて稀な社会で，日本社会の歴史は，外 来の諸制度を柔軟に受容しながら社会全体として決し て受容しなかった。 日本社会は矛盾世界観をもち矛盾 の存在を容認する社会であり，矛盾許容社会では，社 会全体に適用されるべき普遍手的な法体系は存在しな い，としている．更に，日本は外来の文化文明を効用 に基づいて受容する．日本社会は，外来の文化文明を そのイデオロギーを抜き去って取り入れ，その基礎と 
なっている普遍規範を拒否し，表面的な形だけを受容 する，と記述している．すなわち，矛盾の存在を容認 する日本社会において近代科学は発生しないという事 である. そして法の解秋で合理的精神から不可解なも のでも矛盾社会として難なく許容するという事を示し ている.

これらの諸要因が影響し，恐らく折角危険源から出 発し，欧米で実践されている安全原則がそこに織り込 まれているにも係わらず, $2 \cdot 2$ 項で記述した様に，日 本の安全法規は現場でそれが厳密に守られないという 実態との遊離を招いていると思われる.

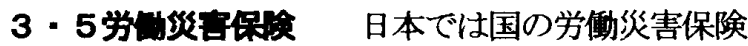
が社会保険の一環として，無過失責任として整備され ており，被災者はそれにより補償を受ける，被災者を 差別無く救済するという観点からは良い仕組みでは有 るが，逆に無過失責任で有るが故に，原因ではなく結 果に対しての補償が行なわれる為，4・4 項及び $4 \cdot 5$ 項で述べる通り安全技術的な再発防止策を構築するに 至らない. $2 \cdot 2$ 項の労働災害事例が示寸様に, 同様な 重大災害が過去繰り返し発生しており，いずれの場合 にも，被災者には事故原因が確定されるか研かに係わ らず，無過失責任制度の性質により保険金は支給され る.この反復性或いは不可逆性は，例えば，典型的な はさまれ・巻き込まれに対し，事故の際にその原因を 追究し, 駆動源に対しての隔離の原則及ひ停止の原則 の実施を徹底する既知の方法を設計者にフィードバッ クしておけば，これら多くの重大災害は基本的に予見 及び回避が可能となる.

その為, 折角危険源とその対応を定めた安衛法及び 安衛則の精神と逆行するという皮肉な結果に至ってい る.ここでは, 本来法律が道守されたという事を前提 として，すなわち災害の対象となった機械の防護は適 切であったか否かの検証の結果, 補償がなされるべき である.

\section{4. 利害間保者の相闻閶保}

科学技術の結果としての事故における責任はリスク とベネフィットのトレード・オフのうえに成立してい る. 欧米のリスク・ベース社会では, 機械は, 社会に 対し利便性を提供するものの，危険源の対応にはそれ に係わる費用が発生する為に, 危険効用論或いは費用 便益分析等を配慮の上で, 残留リスクが製造者により 定められ，一般的にはこれを社会が認めるという構図 になっている. 重要な事は, 事故の基になる危険源を 誰が管理しているかであり，危険源の管理が設計者か
ら使用者へ移転する際の各利害関係者の立場を，以下 に考察する.

4・1 設社者（组浩者） 欧州では法的拘束力 を有する欧州機械指令に基づく CE マーキング制度に より，機械製造者は安全の妥当性を証明できる機械の み市場に流通することが義務付けられており，機械の 設計者責任が明示されている. 訴訟大国であるアメリ 力の場合, 事故が起きた際の製造物責任訴訟の賠償額 で製造者は痛手を蒙る為に，事前に安全な機械を流通 するような慣習となっている. リスクアセスメントを 定めた安衛法第 28 条の 2 の対象は機械使用者(事業者) である為に，機械設計者は安衛法で定める限定された 特定機械以外については，対象外となっている．機械 に内在する多数の危険源は，使用者側では判断しにく く，あくまでも機械設計者がこれを設計的に対処する ことが, 安全確保の基本となる.

4-2 事莱者（使用者）事業者は，同様にリ スク・ベース社会でない事から，事前の設計による予 防概念よりも, 事故が起きた際に如何に迅速に対応し, 再発防止策を講じることが出来るかが重要とされてき た. 又，事故が起きても日本は欧米のような訴訟社会 ではないが故，功利的な観点からは，その方が経済的 であるという風潮が一般的である. 又，事業者にとつ ては経済活動を実践する上で生産性の向上・維持が最 大の重要課題のひとつであるが為に，どうしても危険 な動きにより機械を停止させる事による稼働率の低下 を著しく阻止するという考えが大勢を占め，これが安 全とのトレード・オフとなっている.

新規機械の調達については, 最新の国内法の改定に 基づき，機械使用者は機械製造者から「理に適った」 リスクアセスメント・シートを製品納入の条件とし， かつその結果妥当性を判断できる体制を作る事が望ま しい.

4 -3 国（立法，行政，司法）日本の場合， 明治以来の殖産興業・富国強兵の政策及び戦後の経済 成長路線が示寸とおり，国指導と財界育成・保護の色彩 が港く，それが現在に至っている。

立法も本来の姿である議員立法はわずかであり，大 方行政が淮備し, 内閣法制局を通過したもののみが, 法案として立法される. 司法の観点からは, 他の先進 諸国と比較し圧倒的に数が少ない并護士や裁判官では 案件処理に限界があり, 結果として和解が数多く存在 する.これら，政官財の鉄の三角形といわれる構造が 安全行政への強い影響を行使し続けてきており，ILO 条約の批准状況から, 日本の場合必ずしも基本的人権 が優先されているとは言えない８時間労働に関する 
1919 年の ILO 第 1 号条約を先進工業国である日本は, 現在に至るまで批准していない.これは，財界にとり 功利的観点から好ましくない為に，批准に対し抵抗が 生じているものと推測される.

\section{4 -4 労楮 (被災者) 日本の労災現場では,} ヒューマンエラーが大半である. 事故が発生し, 該当 機械に安衛則で定める危険源の管理が施されていない 場合であっても，注意不足で事故を引き起こしてしま い, 生産ラインを停止する事により稼働率が下がり, 会社に迷惑をかけてしまった，というとらわれ方が一 般的で，危険な機械が防護されていなかったために， 事業者の安全配虑義務が不充分であった，或いは機械 製造者が充分な安全性を確保していなかったという論 調には大方ならない，一般的に，事故が起きても労働 者はその人的責任を請負い労働災害保険が適用される 場合には，それにより補償を受け，一件落着となる. 同様に，該当機械に安衛則で定める危険源の管理が施 されていない場合でも，機械製造者はおろか安衛法の 主体者である事業者が被告となり敗訴する判例は国内 の場合極めて少ない：これは, 恐らく事故の発生要因 としての危険源の設計段階並びに使用者の管理段階で どの上うに処理されるべきかの工学的な抗弁材料が被 災者側に充分に用意されていない事が要因として考え られる。

法学者の三柴 ${ }^{(8)}$ は, 日本の安衛法の特質及び, ドイ ツの場合労動者の権利につき以下の通り説明してい る;

国内の安衛法は，その成立過程からして明治以来の 官主導型取締法の性質をもち, 労働の主体者である労 働者の権利を擁護するという観点から出発していない. ドイツの安衛法では, 各労働者に対し第一に職場危険 に関する情報権，第二に危険有害業務に際しての労務
拒否権, 第三に危険状態の積極的是正を求める履行請 求権等が規定されている. 日本の場合は，これら労働 者の権利が確立していない為に, 指摘或いは是正要求 が出来ない。

安全配慮義務に詳しい法学者で弁護士の安西(9)は, 同様の理由により個別法としての安衛法からの対応の 限界を指摘の上で，国民安全基本法制定の必要性を説 いている.

4.5 辂道撒関 事故がおきると，報道機関は 一斎に誰が悪いかを焦点として報道活動を開始する. 技術の関連で事故が起きた際には，国際的にはリスク・ ベースの観点から，何故事故が起きたか，その際に設 計者，事業者はなすべき事を実践してきたが本来問わ れるべきである．図2 に示す通り日本では，技術の問 題はさておき，直ぐに人的答責問題に集約すると，技 術改善による事故の再発防止にはなかなかつながらず， 似たような事故が再発を繰り返す，事故の現象に焦点 を当てるのではなく，社会に利便性を提供する科学技 術とそれに伴い危険源から発生するリスクを事前に充 分に管理されていたかが，本来問題とされるべきとこ ろである.

\section{RBA 椾の成立}

平成 18 年 4 月に安衛法が改正施行され，第 28 条の 2 が新に追加された. その第 1 項では，事業者は，... 危険性又は有害性などを調查し，その結果に基づい て，．．，必要な措置を講ずるよう努めなければなら ない（中略及び以下略）とし，第 2 項では，厚生労㗢 大臣は．．．その適切かつ有効な実施を図る為必要な 指針を公表する，とある. 平成 19 年 7 月には，それを 受けて平成 13 年に策定された「機械の包括的な安全基

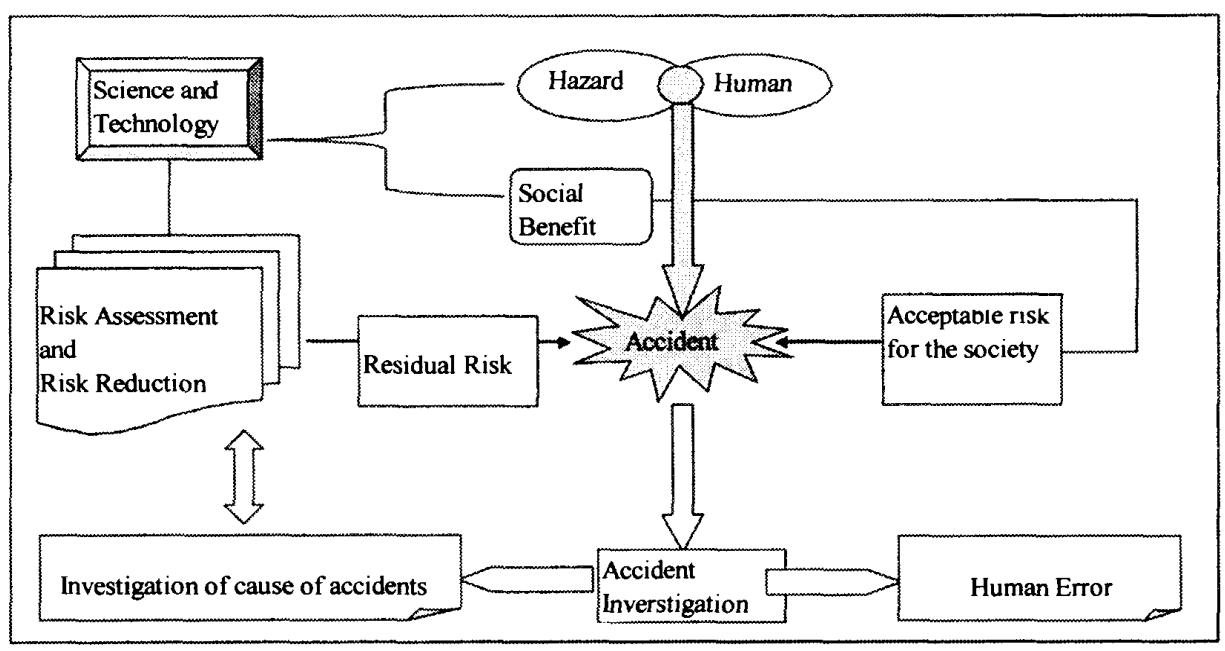

Fig.2 Accident and Responsibility 
淮に関する指針」（以下包括指針）が通達基発第 0731001 号により改定された。

別の表現に置き換えると，これは(1)国際規格などで 定義されたリスクアセスメント及びリスク低减を実施 するという国際的に認知された予防概念としてのリス ク・ベースド・アプローチ（RBA）の考えが法律で明 記され，かつ(2)改正包括指針とその解説（基発第 0731004 号）において，国際機械安全に関する民間の 日本工業規格（JIS）が引用された事である. 平成 13 年当初の包括指針策定時には，機械類に関する国際安 全規格の JIS 整合が不充分であったが，これまでに設 計者が具体的に安全な機械を設計できる主な国際規格 はJIS 化済みである。

ここでは，安全の用語を定義した ISO/IEC Guide 51:1999 で定める色険源の同定, リスクの見積り, 評 価そしてリスク低减という国際的な方法論であるリス クへのアプローチの概念が整合された事のみならず， 法律では具体的な基準を示さずに方向性だけを定め, それをどう達成するかは民間に任せるという官と民の 役割分担を OECD の定める規制改革の理念に則った 欧州機械安全体系の構図と同じ骨組みが出来た事を意 味している.

欧州の場合 1980 年代後半に,ニューアプローチ関連 指令により欧州域内の自由な流通を円滑にする為，機 械指令, 電磁両立性指令, 低電圧指令等により, 個々 の指令では詳練な技術的要求を規定せずに，必須要求 というやや抽象的な要求のみを規定しており，製造者 が製品流通時には，それらの安全要求に適合している 事を自己宣言するCE マーキング制度が導入された. 他方では，適合性評価を国際的に円滑に進める為に， 標淮化作業に関する WTO/TBT 協定との関連性も鑑み グローバルアプローチ指令が発令され，ワン・ストッ プ・テスティングの概念が打ち出された.

しかしながら，RBA 概念は出来たにしても，危険な 機械の流通に関する表示制度は国内の場合特定機械を 除きこれからの課題として残っており. 更には，この RBAの概念を当該官庁関連団体の限られた資源で国 内の全事業所に対して普及活動を推進するに関しては, 改善の余地がある.

又, この RBA 概念とその実践方法を熟知した専門 家の育成がこれまで殆ど実施されてこなかった為に， 事業者や設計者が相談をしたくても，的確な人材が非 常に限定されている.

同時に定められたリスク低减の妥当性を検証できる 認証機関が国内では皆無の為, 事業者や設計者はRBA に基づく新技術などを開発し実際に使用寸る際の安全
の妥当性の判断につき現状では路頭に迷うという実態 がある.

RBA 概念を適用するに際しても, 安衛法は厚生労働 省，JS は経済産業省の所轄という事で分担されてお り，設計者及び事業者に対しての一貫した責任体制或 いはその責任区分が明確でないという課題が残る.ア スベスト問題のように, 事業所の敷地内は安衛法が適 用される為に厚労省が所轄であるが，その敷地を一歩 出たとたんにその規制の対象外となり, 事業所に隣接 した住民の有害物質による健康被害については環境省 の管轄となるという事では，被災者が均一に納得でき る説明を得る事に支障が生じる.

司法制度改革審議会により 2001 年 6 月 12 日に提出 された意見書によれば, 司法改革の理念的基礎として 法制度の「事前から事後へ」が明示されているが，こ れは行政改革からの視点であり, 安全につき, 人権擁 護の視点からは「事後から事前一」という国際的な潮 流を度外視する事はできずに, それ故, 安衛法で事前 の RBAの概念が打ち出された事は特筆される事であ る.

\section{6. 結解}

機械に関する日本の安全のしくみは，3·2に示した 労衝災害死亡者数の比較から他の工業先進国と比較し 遅れているとはいわれるが，機械安全の基本である危 険源の管理については，幾つかの問題を含みながらも 明治以降，法律で明示されている事を検証した。 しか しながらその解釈と運用が国内の場合それ程厳密では なく, 例示された労働災害の事故原因から見ても, 法 令順守が必ずしもなされていないという事が示された. 体制的にも客観的な危険源とその対応を技術で運用す るという実態になっていない，背景としては，安衛法 の設立経緯として官主導による取締法としての性格と 経済優先主義により人権は優先順位を勝ち得ていなか った事, 並びに日本と日本人の特質性等があげられる. 客観的, かつ確定的な危険源に着目した工学に重きを おいたリスク・ベース社会の構築が必要である.

改正安衛法では RBA の概念が示され, 改正包括指 針では技術的方法論が示された事により RBA の実践 が可能となった.

機械の駆動源並びに動力伝達装置は危険源の典型で あり，リスク発生以前にこれら確定的危険源を覆い，

囲う，そして危険なときに機械を停止する等，誰もが 理解しやすい理屈を実践寸る事が最優先される. しか も，期間を区切り集中的に活動を実施すべきである. 
典型的な災害事例が示すとおり，危険源の管理を定め ている安衛則にうたわれている様に,危険源に対し「隔 離の原則」及び「停止の原則」を遵守する事により大 方の事故は，予見可能であり，結果回避可能であり， かつ再発防止可能である. すなわち，国際化が話題と される現在, 労働現場に置ける安全の達成とそれによ る労働災害の予防及び労働災害数の低下は，国際規格 がうたう安全の原則をとりわけ強調することが無くと も，国内の現存法体系の中に含蓄されているというこ とである. 国際規格のリスクアセスメント原則は，そ れを実践する為の補足的，かつ具体的な方法論である. このように，国際規格の機械安全体系を語る前に，日 本では法の定めと実態が現状では遊離しているという 認識を持つことが重要であり，行政の課題として，こ の点, 世論への伝達能力の改善が必要不可欠であり,

具体的な方策が必要とされる.

現在安衛法では，事業者の注意義務が明記されるに とどまり，事業者としては，外部で設計されて調達す る機械の危険源を見極めるには限界がある．危険源と いう客観的・確定的な物理的要素に対しこれらを設計 上対処する設計者の責任が ILO 第 119 号機械防護条約 の精神に則り，日本でも国内法で明文化されることが 本来望ましい。

又, 労災保険が無過失責任として支給される前提と して，機械防護は適切であったか，リスクアセスメン 卜は実施され，かつ相応なリスク低减がなされていた か等をインセンティブ制度として導入し評価の上で保 険料率に反映させる，かつ安全原則を技術的に理解し た職員が, 定期的に法に基づいた查察を実施する事が, 予防措置には効果的であると考える．更には，災害が 発生した設備については，基本的に運転再開前に，妥 当なリスクアセスメントが実施される事が本来自明の 理であり，ここで第三者が運転開始前の技術対応の妥 当性を確認できる仕組みが望ましい．

同時に，安全が現在では厚生労働省，国土交通省， 農林水産省, 文部科学省等複数の管轄官庁に分断され ており，人の生命を守るという普遍的な人権の観点か らすれば，綐割省庁により分断されている個別の法律 の改善をもとめるよりも，普遍的な科学技術に立脚す る合理的精神に基づき，法の原点から出発した正義と 権利を踏まえ，例えば安全基本法 ${ }^{(10)} の$ 策定という手段 をもって工業先進国として人権擁護のための共通項と しての基本的枠組みを設定する事が，世界の工業先進 国で実践されてきた規制改革の観点からは全てのステ 一クホルダにとって最善の解決策が生まれるものであ ろうと思われる。

\section{制 辞}

本論文の作成にあたり，法学者である三柴丈典氏， 安西愈氏，又貴重な工場危害予防及ひ衛生規則を HP で公開されている三上喜貴長岡技術科学大学教授，そ の他多数の方々に協力を頂いた事を感謝申し上げる.

\section{女}

(1) Neudoerfer, A. Konstruieren sicheheitsgerechter Produkte, 3.Auflage, Springer (2004).

(2) Kabe, T., Tanaka, K., Someya, M., Sugimono, N., Safety Design of Machinery: a priori prevention (Analysis of database $\mathrm{n}$ industrial accidents), JSME C Vo.73-734 (2007).

(3) Umezaki, S., Shimizu, S., Analysis of Fatal Accident Caused by Industrial Machines, NIIS-SRR-No.,33, NIIS (2005).

(4) Sugimoto, N., Futsuhara, H., Principles of Safety, JSME C Vo.56- 530 (1990), pp.2601-2609.

(5) Maruyama, M., Theory and Action of Modern Political Science, Miraisha (1957).

(6) Kawashima, T., Legal Mind of Japanese People,Iwanami Shinsho (1967).

(7) Ichikawa, A., Inside Society, Tolerable Action Methode, RISTEX (2003).

(8) Mishiba, T., Introduction to the Labour Safety and Health Law, Shinnzannsha (2000).

(9) Anzai, S., Research Rebort on Promotion of theConcept of Safety of Machinery, METI-Research Report on proceeding the concept of safety of machinery, The NPO Safety Engineering Laboratory (2007).

(10) Kabe, T., Perspective approach to a fundamental law on safety, Proceedings of anmual meeting of JSSTS (2005). 